\title{
COVID-19 и ничейный мир: каковы последствия для Европейского Союза?
}

\section{Ральф Ролофф 1}

Европейский центр исследований по вопросам международной безопасности им. Джорджа К. Маршалла, https://www.marshallcenter.org

Университет Бундесвера, Мюнхен, https://www.unibw.de/home-en

Резюме: В этой статье анализируется реакция EC на COVID-19 на фоне меняющейся международной среды, которая характеризуется глобализацией и глобальным смещением центров могущества. Это поднимает вопрос о последствиях нынешней пандемии COVID-19 и кардинальных изменений в международной системе для внутреннего и внешнего развития ЕС. В статье выдвигается предположение, что ЕС может воспользоваться этой возможностью и приобрести большее влияние на мировом уровне, если будет использовать свою силу в качестве менеджера взаимозависимостей посредством создания норм и формирования правил, а также проявлять свое влияние в качестве центрального узла в транснациональных сетях. Внутреннее единство, поддержка прав человека и демократии, а также сильная роль в глобальном управлении являются предпосылками для этой особой нормативной и трансформирующей силы ЕС.

Ключевые слова: COVID-19, солидарность EC, глобализация, политика по вопросам климата, торговая политика, политика развития Европейского оборонного союза, стратегический диалог ЕС-США

1 Автор благодарит рецензентов за полезные комментарии, которые помогли улучшить аргументацию статьи. 
... если просто сказать то, что мы узнали от эпидемий, так это то, что в людях есть больше того, чем можно восхищаться, чем того, что надо презирать. - Альбер Камю, Чума

\section{Введение}

Для Европейского Союза на карту поставлено многое. Германия принимает председательство в ЕС от Хорватии 1 июля 2020 года. То, как Германия справится с председательством ЕС, будет иметь первостепенное значение для будущего Европейского Союза. ${ }^{2}$ Перед председательством Германии в ЕС стоит сложная задача, поскольку COVID-19 подвергает Европейский Союз внутреннему и внешнему давлению. Пандемия влияет на внутренние показатели ЕС в плане борьбы с экономическими, социальными, политическими и медицинскими последствиями COVID-19, а также на способность ЕС действовать в глобальном масштабе и вносить значительный вклад в глобальный кризисный менеджмент пандемии. Председательство Германии в ЕС должно будет укрепить 1) внутреннюю сплоченность ЕC, 2) гражданские права, права человека и демократию внутри и вокруг ЕС и 3) глобальную роль ЕС. ${ }^{3}$ Каждая из этих задач представляет собой тяжелую программу на шесть месяцев председательства в ЕС, и в целом они являются титанической проблемой.

В этой статье будет проанализирована реакция EC на COVID-19 на фоне резко меняющейся международной среды, которая характеризуется глобализацией и глобальным сдвигом центров могущества. Это поднимает вопрос о последствиях нынешней пандемии COVID-19 и кардинальных изменений в международной системе для внутреннего и внешнего развития ЕС. В статье утверждается, что ЕС может воспользоваться этой ситуацией и расширить свое влияние на глобальном уровне, если он будет использовать свою силу в качестве менеджера взаимозависимостей посредством создания норм и формирования правил, ${ }^{4}$ а также использовать свое влияние в качестве центрального узла в транснациональных сетях. Внутренняя сплоченность, поддержка прав человека и демократии, а также сильная роль в глобальном управлении являются предпосылками для этой особой нормативной и трансформирующей силы ЕС.

2 Sebastian Groth, "Drei Fragen an ... Sebastian Groth," Internationale Politik 3 (May/ June 2020), p.6, https://internationalepolitik.de/system/files/article_pdfs/IP_032020_Drei-Fragen.pdf.

3 Daniela Schwarzer, “Die Bewährungsprobe," Internationale Politik 3 (May/June 2020): 26-29.

4 Nathalie Tocci, "On European Power," IAI Papers 19 (Rome: Instituto Affari Internazionali, December 2019), https://www.iai.it/sites/default/files/iaip1925.pdf. 


\section{COVID-19 и ничейный мир}

Международная система находится в периоде перехода от либерального мирового порядка, в котором доминирует Запад, к новому би-, мульти- или даже поли-центричному миру. ${ }^{5}$ Переход могущества от одного центра к другому - это период неопределенности, нестабильности и конфликтов. За последние три десятилетия международная система превратилась в сильно взаимосвязанную, взаимозависимую и сложную сеть международных и транснациональных отношений, которая движется цифровой революцией, требующей наличия способности формировать взаимозависимости и осуществлять их менеджмент. ${ }^{6}$

На протяжении как минимум четырех лет, в международных отношениях мы наблюдали резкий переход от постмодернистской парадигмы глобализации и взаимозависимостей и акцента на безопасности человека, демократии, верховенстве закона и человеческом развитии в сторону реалистической парадигмы. ${ }^{7}$ Были разработаны внешняя политика и политика и стратегии безопасности, которые можно охарактеризовать как «реализм каменного века» (Стивен Уолт) с возвращением национального государства в качестве доминирующего субъекта, девальвацией глобализации и возрождением меркантилизма, ростом националистического популизма и авторитарной политики, мышлением в понятиях национальной безопасности, конкуренции великих держав и глобального сдвига центров могущества. Интеграция, сотрудничество и глобальное управление, как преобладающая модель международной и региональной политики, ставились под сомнение задолго до того, как китайское правительство объявило о существовании нового коронавируса 31 декабря 2019 года. $^{8}$

Глобальная пандемия COVID-19 привела к самому серьезному глобальному кризису со времен Великой депрессии и Второй мировой войны. Она уже показала, что драматическое отсутствие международного сотрудничества и лидерства со стороны США, Китая и России доказало, что парадигма Великой силы и вся связанная с ней политика бесполезны и даже опасны

5 Richard Haass, "How a World Order Ends: And What Comes in Its Wake," Foreign Affairs (January/ February 2019), https://www.foreignaffairs.com/articles/2018-1211/how-world-order-ends; G. John Ikenberry, "The End of Liberal World Order?" International Affairs 1 (2018): 7-23; European Strategy and Policy Analysis System (ESPAS), Global Trends 2030 - Citizens in an Interconnected and Polycentric World (Paris: Institute for Security Studies, 2012), https://espas.secure.europarl.europa.eu/ orbis/sites/default/files/espas_files/about/espas_report_ii_01_en.pdf.

6 Paul Kennedy, Preparing for the Twenty-First Century (New York: Random House, 1993).

7 Carlo Masala, Weltunordung. Die globalen Krisen und das Versagen des Westens (München: C. H. Beck, 2016); ESPAS, Citizens in an Interconnected and Polycentric World.

8 Peter van Ham, European Integration and the Postmodern Condition: Governance, Democracy, Identity (New York, NY: Routledge, 2013). 
для разрешения требующего действий, критически важного глобального кризиса. Политика соперничества великих держав столкнулась с вызовами глобализации - и претерпела драматический провал. Отсутствие мирового лидерства со стороны США, Китая и России во время кризиса COVID-19 можно представить как своего рода «момент нулевой гравитации». ${ }^{9}$ Момент нулевой гравитации - это вакуум власти в международной политике из-за того, что ни одна страна или группа стран не располагает рычагами ни политическими, ни экономическими, - чтобы пропагандировать и продвигать международную повестку дня или чтобы обеспечить глобальные публичные блага. Чарльз Купчан характеризует такой сценарий как «ничейный мир». ${ }^{10}$

Совет Безопасности ООН заблокирован неспособностью великих держав согласовать резолюцию о глобальном призыве к прекращению огня в войнах и конфликтах. Борьба США с ВОЗ отнюдь не помогает в организации менеджмента международных кризисов. Политика дезинформации Китая в самом начале кризиса была явным признаком отсутствия международной ответственности и лидерства. Не говоря уже о продолжающихся усилиях России в кампаниях дезинформации в Европе, направленных на подрыв доверия к западным правительствам.

Таким образом, продолжающаяся конкуренция великих держав может затмить собой много неотложных глобальных проблем, связанных с пандемиями и общественным здравоохранением, изменением климата, продовольственной безопасностью, кибербезопасностью и глобальным неравенством, которые требуют совместных международных ответных действий. ${ }^{11}$

Несмотря на эту мрачную картину «ничейного мира», мы не живем в эпохе без глобального управления! Управление сложными взаимозависимостями на основе сотрудничества через международные институты, региональную и межрегиональную интеграцию, формальные и неформальные политические сети имеет место и обеспечивает инновационные формы глобального управления. “Социальная власть», определяемая как «способность устанавливать стандарты, создавать нормы и ценности, которые считаются законными и желательными, без применения принуждения или

9 Ian Bremmer, Every Nation for Itself: Winners and Losers in a G-Zero World (London: Penguin, 2012).

10 Charles A. Kupchan, No One's World: The West, the Rising Rest, and the Coming Global Turn (New York: Oxford University Press, 2012).

11 Ernst Ulrich von Weizsäcker and Anders Wijkman, Come on!: Capitalism, Shorttermism, Population and the Destruction of the Planet - A Report to the Club of Rome (New York, 2019); International Military Council on Climate and Security (IMCCS), The World Climate and Security Report 2020 (Brussels, February 2020), https://climateandsecurity.files.wordpress.com/2020/02/world-climate-securityreport-2020_2_13.pdf. 
оплаты», остается актуальной. ${ }^{12}$ Общества и государства с общими ценностями продолжают тяготеть друг к другу. ${ }^{13}$

С точки зрения взаимозависимости, мир во многом организован как транснациональная сеть с узлами или центрами вместо полюсов могущества в качестве строительных блоков. Количество и качество двусторонних и многосторонних отношений будут определять влияние государств и политических субъектов. Мы вошли в «многоузловой» мир с тремя основными узлами в сети: США, Китай и ЕС. ${ }^{14}$ Глобализация изменила значение понятия 'могущество'. В дополнение к классическим материальным возможностям, таким как валовой внутренний продукт (ВВП) и оборонные расходы, ключевым фактором является то, насколько хорошо международный субъект может влиять на других посредством экономической торговли, военных трансфертов и членства в региональных и глобальных организациях. Так называемый Индекс способности к двустороннему внешнему влиянию (СДВВ) представляет гораздо более дифференцированную и детальную картину распределения глобального влияния: «В глобальном масштабе влияние сосредоточено в руках немногих, и только десять стран обладают примерно половиной мирового влияния. Сегодня Соединенные Штаты обладают 11 процентами глобального влияния. Далее следуют Германия и Франция с примерно 9 \% и 7 \% соответственно. Китай занимает четвертое место и оказывает около 6 процентов мирового влияния. Вообще говоря, члены Европейского Союза хорошо показывают себя в Индексе СДВВ благодаря их высокому уровню континентальной взаимозависимости. Пять из семи оставшихся в первой десятке стран являются европейскими государствами: Италия, Великобритания, Нидерланды, Испания и Бельгия. Россия замыкает список и занимает восьмое место с 4 процентами мирового влияния ». ${ }^{15}$

Учитывая, что шесть государств-членов Европейского Союза входят в первую десятку «глобальных влиятельных субъектов», на которые приходится около 30 \% глобального влияния согласно индексу СДВВ, Европейский Союз имеет потенциал играть гораздо более заметную глобальную роль, используя свою нормативную и преобразующую силу и устанавливая нормы и правила в глобализованном мире.

Как Европейский Союз ориентировался в множественном глобальном кризисе COVID-19 в условиях сложного, конкурентного, взаимосвязанного и глобализованного мира?

12 Peter van Ham, Social Power in International Politics, The New International Relations series, $1^{\text {st }}$ Edition (New York: Routledge, 2010).

13 Florence Gaub, Global Trends to 2030: Challenges and Choices for Europe (Brussels: European Strategy and Policy Analysis System, April 2019), www.iss.europa.eu/ sites/default/files/EUISSFiles/ESPAS_Report.pdf.

14 Jonathan D. Moyer, Tim Sweijs, Mathew J. Burrows, and Hugo van Manen, Power and Influence in a Globalized World (Washington, DC: Atlantic Council, January 2018).

15 Jonathan D. Moyer et al., Power and Influence in a Globalized World, p. 11. 


\section{Ответ Европейского Союза на COVID-19}

Политическая система Европейского Союза как многоуровневая система принятия решений, обладающая способностью действовать наднационально на международном, многостороннем и транснациональном уровнях, ${ }^{16}$ хорошо подходит для менеджмента транснационального глобального кризиса здравоохранения, который превратился в экзистенциальный социальный, экономический кризис и кризис безопасности. Лидерство и солидарность необходимы для успешного прохождения Европейского Союза через этот экзистенциальный кризис. Этот тривиальный призыв к лидерству и солидарности как никогда важен для того, чтобы спасти европейский проект от развала и Европу от падения в темные времена национализма. Лидерство и солидарность важнее, чем во время любого из многих кризисов, через которые прошел Европейский Союз с момента своего основания. ${ }^{17}$

На ранних этапах кризиса COVID-19 в Европе EC не демонстрировал большого присутствия. ${ }^{18}$ Конечно, это вызвало много критики. В самом деле, ЕС не предпринимал действий в начале эпидемии COVID-19, поскольку общественное здравоохранение не входит ни в исключительную, ни в общую компетенцию ЕС. Общественное здравоохранение является национальной компетенцией и ЕС имеет только вспомогательные компетенции в соответствии с Лиссабонским договором: «Союз может осуществлять действия для поддержки, координации или дополнения действий государств-членов по защите и улучшению здоровья людей». Государства-члены первоначально действовали в одностороннем порядке в соответствии со своими национальными правилами на случай непредвиденных обстоятельств. Достаточно красноречиво то, что большинство критиков исходили из того, что ЕС, конечно, должен играть заметную роль в общественном здравоохранении!

Когда большинство границ в Шенгенской зоне было закрыто в результате односторонних действий и без дальнейшей координации, Комиссия ЕС впервые вмешалась, напомнив государствам-членам EC об их обязательствах. Негативным последствием нескоординированного закрытия границ между странами-членами стало нарушение цепочек поставок внутри ЕС. Это, конечно, было непреднамеренным последствием второго порядка односторонних действий, что заставило комиссию ЕС вмешаться в защиту единого рынка.

16 Ralf Roloff, "Die Außenbeziehungen der Europäischen Union zwischen Globalisierung und Regionalisierung," Zeitschrift für Politikwissenschaft 11, no. 3 (2001): 1045-1072.

17 Tony Judt, Postwar: A History of Europe Since 1945 (London: Heinemann, 2005); Ian Kershaw, To Hell and Back: Europe 1914-1949 (The Penguin History of Europe) (London: Penguin Books, 2016); lan Kershaw, Roller-Coaster: Europe, 1950-2017 (London: Penguin, 2017).

18 Florence Gaub and Lotje Boswinkel, "Who's First Wins? International Crisis Response to COVID-19," European Union Institute for Security Studies (EUISS) Brief 11, May 20, 2020, www.iss.europa.eu/content/who\%E2\%80\%99s-first-wins-international-crisisresponse-covid-19. 
На первый взгляд, антикризисный менеджмент ЕС казался нескоординированным и показывал неадекватность ЕС, но если присмотреться внимательно, видно, что ЕС взял на себя гораздо больше ответственности и действий по кризисному менеджменту, оказывая немедленную помощь тем людям и государствам-членам, которые больше всего пострадали от COVID19, в частности Италии, Испании и Франции. Активные знаки солидарности европейских народов, граждан, регионов, стран-членов ЕС и ЕС с наиболее нуждающимися в наиболее пострадавших странах были очень впечатляющими: оказание помощи путем отправки медицинских материалов, медицинских работников, обеспечение мест для наиболее пострадавших пациентов в больницах и реанимациях, защита медицинских работников и граждан и возвращение граждан ЕС со всего мира в ходе крупнейшей эвакуационной операции за всю историю, более 60000 оказавшихся в затруднительном положении граждан ЕС были доставлены домой. ${ }^{19}$ «Не говорите пренебрежительно об этом», - предупредил Стефан Корнелиус, один из ведущих немецких обозревателей еще в начале апреля 2020 года. Его предостережение взывало к активной солидарности и коллективной реакции ЕС.

COVID-19 представляет собой проверку солидарности государств-членов EC, солидарности общества (обществ) ЕС, экономики ЕС при блокировке всех экономик, институциональной устойчивости ЕС и, таким образом, европейского проекта. Реакция Европейского Союза на COVID-19 после начального периода национальных ответов и пакетов мер на случай непредвиденных обстоятельств была очень впечатляющей. Общий ответ ЕС в денежном выражении составляет 3 триллиона евро. Ответная реакция 20 ЕС на коронавирус состоит из медицинских, пограничных и связанных с мобильностью экономических мер, содействия исследованиям, в том числе для вакцины, и борьбы с дезинформацией, поскольку пандемия с самого начала сопровождалась «инфодемией». ${ }^{21}$

Механизм комплексного политического реагирования на кризис (КПРК) был запущен очень рано, чтобы координация, консультации и обмен информацией между ЕС и его государствами-членами могли быть организованы в соответствии с четко установленными процедурами. 13 марта 2020 года Комиссия ЕС представила Скоординированную экономическую реакцию на коронавирус в ЕС с полным каталогом экономических и финансовых инструментов и программ. 9 апреля 2020 года Европейский совет приступил к принятию комплексных мер экономической политики, которые могли во многом рассчитывать на механизмы, созданные после кризиса Еврозоны. Все институты ЕС поддержали быстро и полностью этот огромный пакет,

19 EU Commission, "Coronavirus: European Solidarity in Action," https://ec.europa.eu/ info/live-work-travel-eu/health/coronavirus-response/coronavirus-europeansolidarity-action_en.

20 EU Commission, “Coronavirus Response," http://www.ec.europa.eu.

21 EU Commission, "EU versus Disinformation," http://www.EUvsDisinfo.eu. 
осознавая срочность и ответственность ЕС: Европейский парламент, Комиссия ЕС, Совет ЕС, Европейский центральный банк, Европейский инвестиционный банк и Еврогруппа. ЕС и его государства-члены согласовали пакеты и меры, которые были немыслимы до COVID-19 из-за внутренних разногласий между экономическими философиями государств-членов. Скорость и масштаб всеобъемлющих ответных мер экономической политики поистине захватывали дух. Даже обсуждение так называемых коронабондов, которые были предметом серьезных споров между Францией, Испанией и Италией, с одной стороны, и Германией, Нидерландами и Австрией с другой, не смогли затормозить коллективный ответ. В конце мая 2020 года Германия и Франция представили компромисс, предложив единовременный фонд спасения в размере 500 миллиардов евро, чтобы помочь экономике EC оправиться от воздействия COVID-19. Средства будут предоставлены в виде грантов наиболее пострадавшим секторам и регионам ЕС. Для сбора средств 27 стран-членов ЕС будут также вместе брать займы на финансовых рынках. Предлагаемые гранты в размере 500 миллиардов евро являются дополнением к бюджету ЕС на 2021-2027 годы, который на этот период приближается к 1 триллиону евро. Предложение Германии и Франции может открыть путь к более крупной сделке внутри ЕС. Предложение Меркель и Макрона может положить конец спору по коронабондам. Европейская Комиссия сделала многолетнюю финансовую рамку для Европы на 2021-2027 годы «матерью восстановления Европы». В рамках текущего бюджета ЕС все неиспользованные средства были предоставлены для реагирования на COVID-19.

В результате несогласованных односторонних действий в начале кризиса 15 апреля 2020 года президент Европейского совета Шарль Мишель и президент Комиссии ЕС Урсула фон дер Ляйен представили «Дорожную карту восстановления». И, что гораздо важнее, совместную европейскую дорожную карту по отмене мер сдерживания COVID-19.

Комплексный экономический ответ включает гибкое использование бюджета ЕС, гибкое использование правил ЕС, денежно-кредитную политику, проводимую Европейским центральным банком, экстренную поддержку, общеевропейский гарантийный фонд, возглавляемый Группой европейских инвестиционных банков, системы социальной защиты Европейского механизма безопасности, ПРБЧС, который представляет собой европейский инструмент временной поддержки для снижения рисков безработицы в чрезвычайной ситуации, предложенный Комиссией ЕС, который позволит предоставить финансовую помощь до 100 миллиардов евро в форме займов от ЕС пострадавшим государствам-членам.

Комиссия ЕС организовала в мае 2020 года глобальный марафон заверений с глобальными партнерами по исследованиям, направленных на разработку вакцины против COVID-19. Проект собрал 7,4 миллиарда евро от доноров со всего мира, включая обещание в размере 1,4 миллиарда евро от 
Комиссии ЕС. В начале июня 2020 года Комиссия ЕС выделила 300 миллионов евро Vaccine Alliance GAVI на период 2021-2025 годов. Финансирование поможет иммунизировать 300 миллионов детей во всем мире и профинансировать создание запаса вакцин для защиты от вспышек инфекционных заболеваний. Франция, Германия, Италия и Нидерланды сформировали альянс для ускорения производства вакцины от COVID-19 в Европе в тесном сотрудничестве с различными фармацевтическими компаниями. Цель «Inclusive Vaccine Alliance» - обеспечить производство вакцины на европейской территории везде, где это возможно, и сделать вакцину доступной во всем мире. ${ }^{22}$

\section{Критические вопросы, связанные с реакцией EC на COVID-19}

Есть критически важные вопросы, связанные с реакцией EC на COVID-19. Каждый из них может сорвать совместные усилия ЕС по урегулированию кризисов.

Наиболее важным аспектом реакции государств-членов на кризис COVID-19 является авторитарный соблазн ограничить гражданские права. Венгерский парламент фактически как раз вовремя предложил Виктору Орбану на серебряном блюдечке неограниченное по времени решение, основанное на чрезвычайном положении, которое позволяет нелиберальной демократии в Венгрии и дальше ущемлять гражданские права, свободу прессы, слова и мнений, деятельность НПО и вводить ограничения для трансгендеров. Польша - другая страна-член ЕС, столкнувшаяся с серьезным авторитарным искушением. Правящая партия ПИС попыталась использовать кризис COVID-19 для продвижения своей повестки дня. Наглядным примером были попытки провести президентские выборы во время изоляции в стране, а также попытки переделать закон об абортах, чтобы практически сделать аборт в Польше юридически невозможным. Радослав Сикорский, бывший министр иностранных дел и обороны Польши, а ныне член Европейского парламента, недавно предупредил, что Польша может быть превращена в католическую диктатуру типа Франко. Это может быть слишком большой натяжкой, но это указывает на серьезность подрыва верховенства закона правительством ПИС.

Миграция и солидарность ЕС по-прежнему остаются одними из самых раздражающих проблем политики ЕС, которые не решены. По мере того, как положение беженцев на греческом острове Лесбос ухудшается буквально изо дня в день, отсутствие солидарности бросается в глаза еще больше. Избавление беженцев от ужасной ситуации в лагерях беженцев, и таким образом, защита их от заражения коронавирусом, - это не только фундаментальный гуманитарный акт, но и акт европейской солидарности.

22 "Dutch, French, Germans and Italians Form Virus Vaccine Alliance," MedicalXpress, June 3, 2020, https://medicalxpress.com/news/2020-06-dutch-french-germansitalians-virus.html. 
Государства-члены Европейского Союза, и в особенности государствачлены из Центральной Европы, все еще отвергают любые компромиссы по вопросу миграции.

Необходимо увидеть, усвоил ли ЕС уроки кризиса евро, сможет ли он проявить солидарность с наиболее пострадавшими странами и полностью поддержать их в процессе восстановления экономики. Это доказательство солидарности с наиболее пострадавшими государствами-членами также является ключом к полному восстановлению Европейского Союза. Разница между COVID-19 и кризисом Еврозоны заключается в том, что COVID-19это симметричный кризис, который затрагивает все страны-участницы, и что влияние COVID-19 не основано на плохом управлении, а это большая разница по сравнению с кризисом евро. Италия и Испания сильно страдают не только от COVID-19, но и от националистически-популистских движений, которым не терпится увидеть падение нынешнего правительства. Они подпитывают антиевропейские настроения в своих странах, что ставит ЕС и его государства-члены в ситуацию, когда им надо возвращать и восстанавливать доверие, которое было утрачено во время кризиса евро, миграционного кризиса, а теперь и во время кризиса COVID-19. ${ }^{23}$

Переосмысление глобализации и глобальной роли ЕС в международной политической экономии - еще одна важная проблема для Европейского Союза. Концепция более зеленой и более цифровой Европы во многом зависит от формы глобализации в ближайшие годы. Европейский Союз создал хорошо организованную и функционирующую сеть межрегиональных и двусторонних всеобъемлющих торговых соглашений, и он управляет хорошо функционирующей сетью межрегиональных отношений почти со всеми важными экономиками и регионами мира. ${ }^{24}$ Во время работы Комиссии Юнкера (2014-2019), которое в глобальном масштабе характеризовалось периодом торговых войн и протекционизма, ЕС заключил торговые соглашения с Канадой, Японией, Вьетнамом, Сингапуром и странами МЕРКОСУР Бразилией, Аргентиной, Парагваем и Уругваем.

Отсутствие поддержки ключевых международных организаций, таких как Всемирная торговая организация, ключевыми игроками, подрывает потенциал ЕС по переформатированию глобализации, но не останавливает ее. ЕС удалось, например, сделать Общий регламент защиты данных доминирующим мировым стандартом в такой весьма спорной и конфликтной области, как кибер домейн, в которой США и Китай являются доминирующими субъектами. ЕС, возможно, будет трудно сделать стандартом свое видение

23 Aureliana Sorrento (2020), "Der Dritte Dämpfer," Internationale Politik 3 (May/June 2020): 30-33.

24 Heiner Hänggi, Ralf Roloff, and Jürgen Rüland, eds., Interregionalism and International Relations: A Stepping Stone to Global Governance? (London and New York: Routledge, 2006); EU Commission, 2019 Report on Implementation of EU Free Trade Agreements: 1 January 2018-31 December 2018 (Publications Office of the European Union, 2019), https://trade.ec.europa.eu/doclib/docs/2019/october/tradoc_158387.pdf. 
углеродно-нейтрального континента к 2050 году. Амбиции ЕС зависят не столько от его энергетической зависимости от России, сколько от внутренних дискуссий стакими странами, генерирующими углерод, как Польша, что безусловно замедлит амбиции ЕС. Зеленая сделка ЕС будет в гораздо большей степени зависеть от его способности поддерживать Парижское соглашение, и при самом благоприятном развитии вернуть Соединенные Штаты обратно в него. В противном случае ЕС будет нелегко поддерживать вместе альянс держав средних размеров или создать прочную коалицию желающих - это означает сохранение приверженности Китая и России к Парижскому соглашению.

\section{COVID-19 и глобальная роль EC}

В контексте глобального вакуума лидерства и недостатков, которые мы видели в борьбе с COVID-19, для EC будут иметь значение три основных вопроса, которые уже имели значение в мире до COVID-19: ${ }^{25}$

- Защита демократии в ЕС, а также за его пределами. Конкуренция политических систем будет продолжаться. ЕС необходимо изменить свою политику устойчивости в отношении третьих стран и, в частности, соседних стран. ЕС должен вернуться к политике поддержки демократии и верховенства закона. Прагматический подход к устойчивости потерпел неудачу. Следовательно, необходимо пересмотреть возвращение позитивной обусловленности в качестве жизненно важного инструмента ЕС.

- Более тесное сотрудничество в области изменения климата и прогресса в переходе к низкому уровню выбросов не только настоятельно требуется подавляющим большинством в ЕС, но и является предварительным условием для амбициозной цели создания континента с нейтральным выбросом углерода к 2050 году. Что необходимо сделать ЕС, это очень тесно увязать его политику в области климата с политикой развития и торговли. Управление программой Парижского соглашения по климату и задачи создания континента с нейтральным выбросом углерода будет работать только в том случае, если ЕС сможет начать осуществлять политику развития, которая серьезно относится к проблеме изменения климата для большинства развивающихся стран, и это позволит им создать достаточный потенциал для решения проблемы продовольственной безопасности, общественного здравоохранения, нехватки воды и опустынивания, и многие другие. ЕС как значительный торговый субъект должен увязывать свою торговую политику с целями своей политики в области климата и развития. Это потребует серьезного переосмысления во многих отношениях, поскольку текущая торговая политика имеет тенденцию подрывать достижение целей

25 Susi Dennison, Mark Leonard, and Pawel Zerka, How to Govern a Fragmented EU: What Europeans Said at the Ballot Box, Report ECFR/287 (European Council on Foreign Relations, June 2019), https://www.ecfr.eu/publications/summary/how_to_govern_ a_fragmented_eu_what_europeans_said_at_the_ballot_box. 
в области климата и развития. Торговое соглашение с МЕРКОСУР является здесь примером, поскольку оно связывает вырубку тропических лесов с торговлей с ЕС. Поэтому крайне важно следить за тем, чтобы на цели в области климата не оказывала отрицательное влияние его собственная торговая политика.

- Необходимо добиться дальнейшего прогресса в оборонной интеграции ЕС. Это необходимо не только из-за стремления к стратегической автономии и создания Европейского оборонного союза, но и в качестве поддержки роли ЕС как торговой державы, нормативной и преобразующей силы. Геополитическая реальность мира «нулевой гравитации» потребует от ЕС стать более стратегически автономным, чтобы иметь возможность защищать своих граждан и Европейский Союз. Постоянное структурированное сотрудничество (PESCO), Скоординированный годовой обзор обороны (CARD) и Европейский оборонный фонд (EDF) - это инициативы, которые могут стать ядром для наращивания потенциала EC и, таким образом, обеспечить основу для реального Европейского оборонного союза. Следует серьезно отнестись к инициативам президента Макрона по Европейской инициативе вмешательства (EI2), а также к его недавнему предложению включить ядерные силы Франции в Европейский союз обороны. Конечно, НАТО продолжит играть важную роль в коллективной обороне Европейского Союза, но усиление европейского элемента в НАТО даст ЕС больше рычагов влияния в трансатлантических отношениях. Поскольку США больше озабочены стратегическим соперничеством Китая и США, Европейский Союз должен взять на себя еще больше ответственности за свою безопасность. Стратегический диалог между ЕС и США по вопросам безопасности и обороны давно назрел. Это можно было бы вписать в контекст треугольника стратегических трансатлантических диалогов: ЕС-США, ЕС-НАТО, НАТО-США.

\section{Заключение}

К этому моменту ЕС показал свою способность адекватно реагировать на экзистенциальный кризис, вызванный COVID-19. Координация между странами-членами очень плотная и, конечно же, ведутся живые дискуссии о наилучшем способе восстановления. Внутренняя сплоченность, поддержка прав человека и демократии, а также сильная роль ЕС в глобальном управлении являются предпосылками для полного выхода EC из кризиса COVID19, а также для повышения потенциала EC как нормативной и преобразующей силы в глобализованном, конкурентном и сложном мире. Есть пять важных элементов:

1. ЕС должен действовать более жестко в защиту демократии внутри ЕС и проводить политику абсолютной нетерпимости к любому проявлению автократического правления в любом государстве-члене ЕС. Ключевым моментом должна быть увязка экономической поддержки со стороны пакета COVID-19 с демократическими ценностями, защитой гражданских прав и 
прав человека, а также верховенством закона. Авторитет Европейского Союза в огромной степени зависит от борьбы с нелиберальными демократиями и любой тенденции к ограничению основных прав сверх ограниченного периода времени, связанного с пандемией COVID-19. Правительства Венгрии, Польши и Чешской Республики также должны находиться под пристальным наблюдением и, в случае продолжающегося несоблюдения договоров ЕС и законодательства ЕС, подвергаться санкциям.

2. Более тесное сотрудничество в области борьбы с изменением климата и прогресс в переходе к низкому уровню выбросов - «зеленая сделка» Европы должна быть поставлена в самый центр программ экономического восстановления. Восстановление экономики не должно происходить за счет «зеленой сделки» - должно иметь место прямо противоположное. Программы восстановления должны использовать возможность реструктурировать европейскую промышленность в сторону зеленой экономики. То же самое относится и к реструктуризации энергетического рынка. Цифровизация развивалась дальше во время кризиса COVID-19. EC необходимо воспользоваться этой динамикой, чтобы еще сильнее подтолкнуть европейские общества и экономики к цифровизации.

3. Усиление роли ЕС в сфере общественного здравоохранения следует рассматривать как урок, вынесенный из кризиса COVID-19. Приватизация значительной части сектора общественного здравоохранения во многих государствах-членах должна быть пересмотрена и заново оценена с точки зрения защиты здоровья.

4. Более широкая и глубокая дискуссия в ЕС о социальных аспектах рыночной экономики и капитализма также должна быть частью восстановления. Европейская модель социального государства в сочетании с рыночной экономикой нуждается в пересмотре и адаптации к требованиям постнеолиберальной эпохи. Цифровизация, изменение климата, реглобализация и более интегрированная международная система, более ориентированная на безопасность человека, чем на национальную безопасность, требуют адаптации со стороны Европейского Союза, а также его государств-членов. Если ЕС, его государства-члены и европейцы смогут адаптировать ЕС к среде после COVID-19, жертвы во время кризиса не были напрасными.

5. Дальнейший прогресс в оборонной интеграции ЕС необходим, чтобы подготовить Европейский Союз к принятию на себя большей ответственности в мире «нулевой гравитации». Конечной целью должна быть стратегическая автономия Европейского Союза. Текущие инициативы PESCO, CARD и EDF, французская инициатива в отношении EI2 и предложение Макрона использовать французский ядерный арсенал для европейской обороны должны быть объединены в Европейский оборонный союз, который действительно способен защитить Европейский союз.

Несомненно, сотрудничество с НАТО имеет решающее значение. Дальнейшее развитие сотрудничества между ЕС и НАТО, в частности в области 
создания потенциала, наращивания потенциала, гибридных угроз, кибербезопасности, а также обучения и учений, важно для успешного использования достижений обеих институций и использования их конкурентных преимуществ. После COVID-19 необходима новая трансатлантическая сделка. Европейский Союз и США должны участвовать в стратегическом диалоге, который мог бы быть частью более широкого стратегического диалога в трансатлантическом сообществе: ЕС-США, ЕС-НАТО и НАТО-США.

Председательство Германии в ЕС в ближайшие месяцы должно управлять этими элементами антикризисного менеджмента EC COVID-19 и восстановления. Это будет настоящая проверка не только для EC, но и для Германии.

\section{Отказ от ответственности}

Выраженные здесь взгляды являются исключительно взглядами автора и не отражают точку зрения Консорциума оборонных академий и институтов изучения безопасности ПрМ, участвующих организаций или редакторов Консорциума.

Издание Connections: The Quarterly Journal, том 19, 2020 осуществляется при поддержке правительства Соединенных Штатов.

\section{Об авторе}

Профессор д-р Ральф Ролофф является заместителем декана по академическим вопросам в Центре им. Джорджа К. Маршалла и адъюнкт-профессором Мюнхенского университета Бундесвера. Он преподавал в Университете Трира, Университете Кельна, Университете им. Йоганнеса Гуттенберга в Майнце и Университете им. Гельмута Шмидта в Гамбурге. Он был стипендиатом центра им. Роберта Шумана в Европейском парламенте и стипендиатом программы Фулбрайта в Нью-Йоркском университете. Он имеет степень магистра и доктора Трирского университета и степень государственного доктора Кельнского университета и Университета Бундесвера Мюнхена. Он широко издается на немецком, английском и французском языках. 